\title{
Stem cell therapy for Crohn's disease: systematic review and meta-analysis of preclinical and clinical studies
}

\author{
Ruo Wang ${ }^{1,2}$, Qigu Yao ${ }^{1,2}$, Wenyi Chen ${ }^{1,2}$, Feiqiong Gao ${ }^{1,2}$, Pan $\mathrm{i}^{1,2}$, Jian Wu $\mathrm{U}^{1,2}$, Jiong $\mathrm{Yu}^{1,2}$ and \\ Hongcui Cao ${ }^{1,2,3^{*}}$ (D)
}

\begin{abstract}
Background: We explored whether stem cell therapy was effective for animal models and patients with Crohn's disease $(C D)$.

Methods: We searched five online databases. The relative outcomes were analyzed with the aid of GetData Graph Digitizer 2.26 and Stata 16.0 software. The SYRCLE risk of bias tool and the MINORS tool were used to assess study quality.

Results: We evaluated 46 studies including 28 animal works $(n=567)$ and 18 human trials $(n=360)$. In the animal studies, the disease activity index dramatically decreased in the mesenchymal stem cell (MSC) treatment groups compared to the control group. Rats and mice receiving MSCs exhibited longer colons [mice: standardized mean difference (SMD) 2.84, $P=0.000$; rats: SMD 1.44, $P=0.029$ ], lower histopathological scores (mice: SMD $-4.58, p=0.000$; rats: $S M D-1.41, P=0.000)$ and lower myeloperoxidase levels $(S M D-6.22, P=0.000)$. In clinical trials, stem cell transplantation reduced the $C D$ activity index $(S M D-2.10, P=0.000)$, the $C D$ endoscopic index of severity $(S M D-3.40$, $P=0.000)$ and simplified endoscopy score for $C D(S M D-1.71, P=0.000)$ and improved the inflammatory bowel disease questionnaire score (SMD 1.33, $P=0.305$ ) compared to control values. CD patients maintained high remission rates for 3-24 months after transplantation.
\end{abstract}

Conclusions: Stem cell transplantation is a valuable supplementary therapy for CD.

Keywords: Stem cells, Crohn's disease, Systematic review and meta-analysis, Crohn's disease activity index, Histopathological score, Colon length, Remission rate

\section{Introduction}

Crohn's disease (CD), a form of inflammatory bowel disease (IBD), is an immune system-mediated, chronic systemic condition characterized by gastrointestinal inflammation and dysregulation of the

\footnotetext{
*Correspondence: hccao@zju.edu.cn

1 State Key Laboratory for the Diagnosis and Treatment of Infectious Diseases, Collaborative Innovation Center for Diagnosis and Treatment of Infectious Diseases, The First Affiliated Hospital, Zhejiang University School of Medicine, 79 Qingchun Rd., Hangzhou City 310003, China Full list of author information is available at the end of the article
}

mucosal-associated immune system $[1,2]$. The annual incidence of CD ranges from 5.0 to 20.2 per 100,000 person-years [3, 4], and CD affects more than 1 million people in the USA. The pathogenesis is complex, featuring disturbance of the innate immune system and reduced gastrointestinal barrier protection. Infections and environmental factors may trigger or exacerbate the disease [5]. Corticosteroids (CSs), immunomodulatory agents, and "biological therapies" including anti-TNF- $\alpha$ antibodies are used to suppress intestinal inflammation. However, standard anti-inflammatory regimes do not halt 
disease progression. Aggressive "biological therapies" are immunogenic, but their effects fade over time [6]. Approximately $25 \%$ of $\mathrm{CD}$ patients are refractory to such medications and respond to surgery only [7]. It is thus critical to enhance $\mathrm{CD}$ remission and reduce recurrence.

In recent years, developments in stem cell (SC) biology and regenerative medicine have revealed that SCs unexpectedly can be used to treat autoimmune diseases. Mesenchymal stem cells (MSCs) and hematopoietic stem cells (HSCs) have been shown to counter rheumatoid arthritis, autoimmune hepatitis, and systemic sclerosis [8]. MSCs exhibit low immunogenicity and immunomodulation. Randomized controlled experiments have shown that local MSCs injection improved CD-related perianal fistulation $[9,10]$. HSCs transplantation restored immune tolerance and relieved CD [11]. SCs have been found to inhibit intestinal inflammation, promote long-term intestinal mucosal healing, and significantly improve patient quality of life, making them a valuable alternative $C D$ treatment. Several studies have evaluated the safety and effectiveness of $C D$ stem cell therapy, but the results remain controversial. We thus systematically reviewed the literature and conducted a meta-analysis on the effectiveness and safety of SC therapy.

\section{Materials and methods Search strategy}

Five databases (PubMed, Embase, the Web of Science, the Cochrane Library, and Clinical Trials.gov) were searched from their inception dates to February 2021. The search string added the keywords focus on Crohn's Disease ("Crohn's Enteritis", "Regional Enteritis", “Crohn's Disease", "Crohns Disease", "Inflammatory Bowel Disease 1", "Enteritis, Granulomatous", "Granulomatous Enteritis", "Enteritis, Regional", "Ileocolitis", "Colitis, Granulomatous", "Granulomatous Colitis", "Ileitis, Terminal", "Ileitis, Terminal", "Terminal Ileitis", "Ileitis, Regional" and "Regional Ileitis") and stem cells ("stem cells" OR "progenitor cells", "hematopoietic stem cells", "mesenchymal stem cells", "bone marrow mononuclear cells"). We also reviewed secondary references. Two researchers independently screened the titles and abstracts of all retrieved articles.

\section{Study selection}

Studies that met all of the following criteria were included: single-arm studies or randomized controlled trials including CD patients or animal studies; studies featuring SC therapy with no restriction imposed on the type of SCs, route of administration, or dose; and the inclusion of human $\mathrm{CD}$ clinical parameters [CD activity index (CDAI) scores, C-reactive protein (CRP) levels, CD endoscopic index of severity (CD-EIS) scores, simplified endoscopy score for CD (SES-CD), inflammatory bowel disease questionnaire (IBDQ) results] or animal disease activity index (DAI) scores, histopathological scores (HSs), colon lengths, myeloperoxidase (MPO) and cytokine levels. Case reports, repeat studies, reviews, and studies lacking full texts were excluded. If more than one article analyzed the same trial, we included only the latest report.

\section{Data extraction and quality assessment}

Two researchers independently evaluated article quality and extracted data by screening abstracts and full texts. A third researcher was consulted to resolve any disagreements. For animal studies, all relevant data were recorded in Microsoft Excel including the first author; year; location; mouse sex, strain, and weight; group numbers; modeling methods; modeling duration; type and source of MSCs; how MSCs were administered; times of treatment; and other parameters. For clinical trials, the following data were recorded: first author, year, location, size of the MSC group, size of the control group, male/ female ratio, type of SCs given, number of SCs administered, administration route, times of treatment, treatment course and follow-up duration. The SYRCLE risk of bias tool was used to evaluate the quality of animal studies [12], and the quality of clinical studies was assessed with the aid of the MINORS tool [13]. We adhered to PRISMA guidelines for this systematic review and metaanalysis [14].

\section{Statistical analysis}

The DAI was calculated from clinical parameters of inflammation (weight loss, diarrhea, and rectal bleeding) that reflect CD severity. CD morphological and pathological changes were represented by the colon length and HS. The MPO level reflected the extent of neutrophil infiltration. The standardized mean difference (SMD) with the $95 \%$ confidence interval (CI) for each parameter was calculated to reveal changes after stem cell therapy in animals. For data from human studies, the means and standard deviations (SDs) of continuous variables (CDAI, CD-EIS, SES-CD and IBDQ scores and the CRP level) were subjected to SMD analysis. We used odds ratios (ORs) with 95\% CIs to determine "remission rates." Medians with percentiles were converted to means with SDs. If only figures were presented, two researchers independently used GetData Graph Digitizer ver. 2.26 to extract data and compute the means [15]. Among-study heterogeneity was examined using the $I^{2}$ test. An $I^{2}$ value $\leq 50 \%$ indicated homogeneity and a fixed-effect model were employed. An $I^{2}$ value $>50 \%$ indicated heterogeneity, and a random-effect model was used instead. Subgroup 
analyses were performed to evaluate heterogeneity. We employed STATA ver. 16.0 to create forest plots and facilitate the meta-analysis. We used the Begg and Egger tests in STATA (with the significance level set to $P<0.1$ ) to evaluate publication bias. All tests were two-sided, and $P<0.05$ was considered to indicate statistical significance.

\section{Results}

\section{Search results}

A total of 1002 studies were retrieved, from which 262 duplications were initially removed. A review of the titles led to the removal of 380 irrelevant papers; a further 243 were excluded after reading the abstracts. A total of 117 full-text studies were carefully reviewed, of which 61 were excluded for lack of data, 10 because they were off-topic, and 1 because the full text was unavailable. Finally, 28 animal studies [16-43] and 18 human studies [44-61] were selected for the meta-analysis (Fig. 1). Funnel plots were used to evaluate publication bias (Additional file 1: Fig. S1).

\section{Animal studies}

\section{Study characteristics and quality}

A total of 487 mice and 80 rats were used; $78 \%$ of all mice were of the C57BL strain, $19.9 \%$ were of the BALB/C strain, and $2.1 \%$ were of the NOD.CB17-Prkdcscid/J strain. Of all rats, $20 \%$ were of the Wistar strain, $42.5 \%$ were of the Sprague-Dawley strain, and $37.5 \%$ were of the Lewis strain. All 28 studies used one of two models: either CD groups consumed dextran sodium sulfate (DSS) in water while controls received regular water or colitis was induced by intrarectal administration of trinitrobenzene sulfonic acid (TNBS) in ethanol (controls received ethanol only). Information on study characteristics, study quality, and publication bias is shown in Table 1, Additional file 1: Table S1, and Fig. S1.

\section{Disease activity index}

Of the 28 studies, $12[16,18-23,25,27,28,31,32]$ reported DAI scores, 9 on day $1 \quad(n=118$ animals), 9 on day $3(n=118), 11$ on day $5(n=134), 3$ on day 7 $(n=124)$, and 5 on day $9(n=64)$. A random effects model was chosen for analysis, and the Cohen method was used to assess differences in DAI between the treatment and control groups. Subgroup analyses showed that the experimental DAI scores were significantly lower than the control scores on day 1 (SMD - 0.99, 95\% CI -1.95 to $\left.-0.02, \quad I^{2}=78.1 \%, P=0.000\right)$, day 3 (SMD - 1.67, 95\% CI -2.54 to $-0.80, I^{2}=72.1 \%$, $P=0.000$ ), day 5 (SMD $-2.08,95 \% \mathrm{CI}-3.14$ to -1.02 , $\left.I^{2}=80.6 \%, P=0.000\right)$, day $7(\mathrm{SMD}-1.84,95 \% \mathrm{CI}-3.17$ to $\left.-0.52, I^{2}=86.4 \%, P=0.000\right)$ and day 9 (SMD -3.63 , 95\% CI -5.58 to $-1.68, I^{2}=79.6 \%, P=0.001$ ) (Fig. 2).
Each subgroup exhibited evidence of heterogeneity, which was alleviated in all but the day 5 subgroup after one or two studies were deleted (Additional file 1: Fig. S2 and Fig. S3). The heterogeneity exhibited by the day 3 and 9 subgroups fell to moderate levels after deleting the studies of Banerjee et al. [23] and Gonzalez-Rey et al. [21]; and Gonzalez-Rey et al. [21], respectively. The heterogeneity associated with the day 1 and 7 subgroup disappeared after excluding Kawata et al. [32] and Forte et al. [16]; Gao et al. [18], Gonzalez-Rey et al. [21] and Ji Young Lim et al. [26], respectively.

\section{Colon length}

As animal colon lengths differ, we evaluated mice and rat data separately. 18 studies $[19,21-26,28-34,36,38$, $39,41]$ described mouse colon lengths $(n=338$ mice). We used a random-effects model to compare colon lengths between treatment and control groups employing the Cohen method. Colon lengths increased markedly in the experimental groups (SMD 2.84, 95\% CI 1.80 to $\left.3.88, I^{2}=87.688 .9 \%, P=0.000\right)$. As the $I^{2}$ value was high, we performed subgroup analysis by MSC type. Subgroup heterogeneity was low except in the bone marrowderived MSC (BM-MSC) group (Fig. 3a).

Three studies $[18,41,43](n=42$ animals) reported rat colon lengths; we again used a random-effect model to compare colon lengths between the treatment and control groups while employing the Cohen method. Colon lengths in the experimental groups were longer than those in the control groups (SMD 1.44, 95\% CI 0.04-2.84, $I^{2}=71.7 \%, P=0.029$ ) (Fig. 3b). Heterogeneity was high; sensitivity analysis showed that this was explained by the work of Gao et al. [18]. After this was excluded, the level of heterogeneity decreased $\left(I^{2}=40.2 \%, P=0.003\right)$ (Additional file 1: Fig. S4).

\section{Histopathological scores}

In mice, compared to the control groups, the HS decreased significantly after transplantation $\left(\mathrm{SMD}-4.58,95 \% \mathrm{CI}-5.80\right.$ to $-3.35, \quad I^{2}=89.6 \%$, $P=0.000$ ). Subgroup analysis by the model used showed that the HS for the DSS group (SMD - 4.96, 95\% CI -6.66 to $\left.-3.27, I^{2}=91.2 \%, P=0.000\right)$ was lower than that for the TNBS group (SMD - 3.76, 95\% $\mathrm{CI}-5.45$ to $-2.06, I^{2}=83.8 \%, P=0.000$ ) (Additional file 1: Fig. S5). Both subgroups exhibited evidence of high heterogeneity. Subgroup analysis by MSC type in the DSS group indicated that BM-MSCs (SMD -6.25, 95\% CI $-11.60 \quad$ to $-0.90, \quad I^{2}=96.1 \%, \quad P=0.000$ ) imparted better effects than did other MSC types (Fig. 4a). The heterogeneity observed in the subgroup analyses was attributable to the studies of Ikarashi et al. [27] and Song et al. [24] in the adipose-derived MSC 


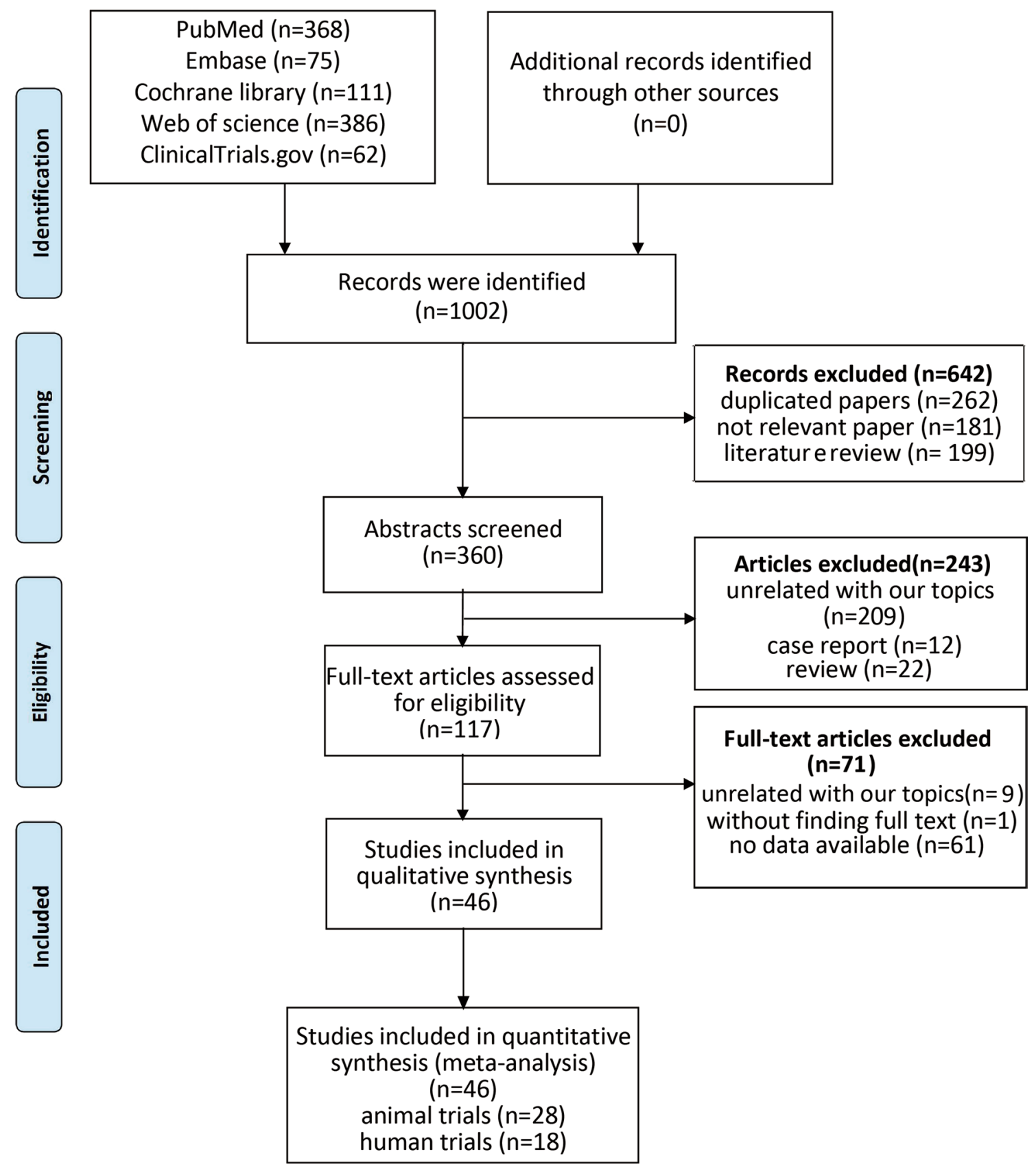

Fig. 1 Flowchart of study selection. A total of 1002 records were retrieved; after application of the inclusion criteria, 28 animal studies and 18 human trials remained

subgroup, Nikolic et al. [41] in the BM-MSC subgroup, and Gonzalez-Rey et al. [21] and Li et al. [39] in the umbilical cord-derived MSC (UC-MSC) subgroup. After excluding these studies, the level of heterogeneity decreased in the adipose-derived MSC subgroup $\left(I^{2}=0\right)$, BM-MSC subgroup $\left(I^{2}=76.5 \%\right)$, and UCMSC subgroup $\left(I^{2}=22.6 \%\right)$ (Additional file 1: Fig. S6). The subgroup analysis of TNBS group decreased the heterogeneity to a lower level (Additional file 1: Fig. S7A).

For the three rat studies [26, 35, 42] ( $n=54$ animals), the HS was lower in the experimental groups than in the control groups (SMD-1.41, 95\% CI-2.02 to -0.81 , $I^{2}=0, P=0.000$ ) and heterogeneity was lacking (Fig. $\left.4 \mathrm{~b}\right)$. 


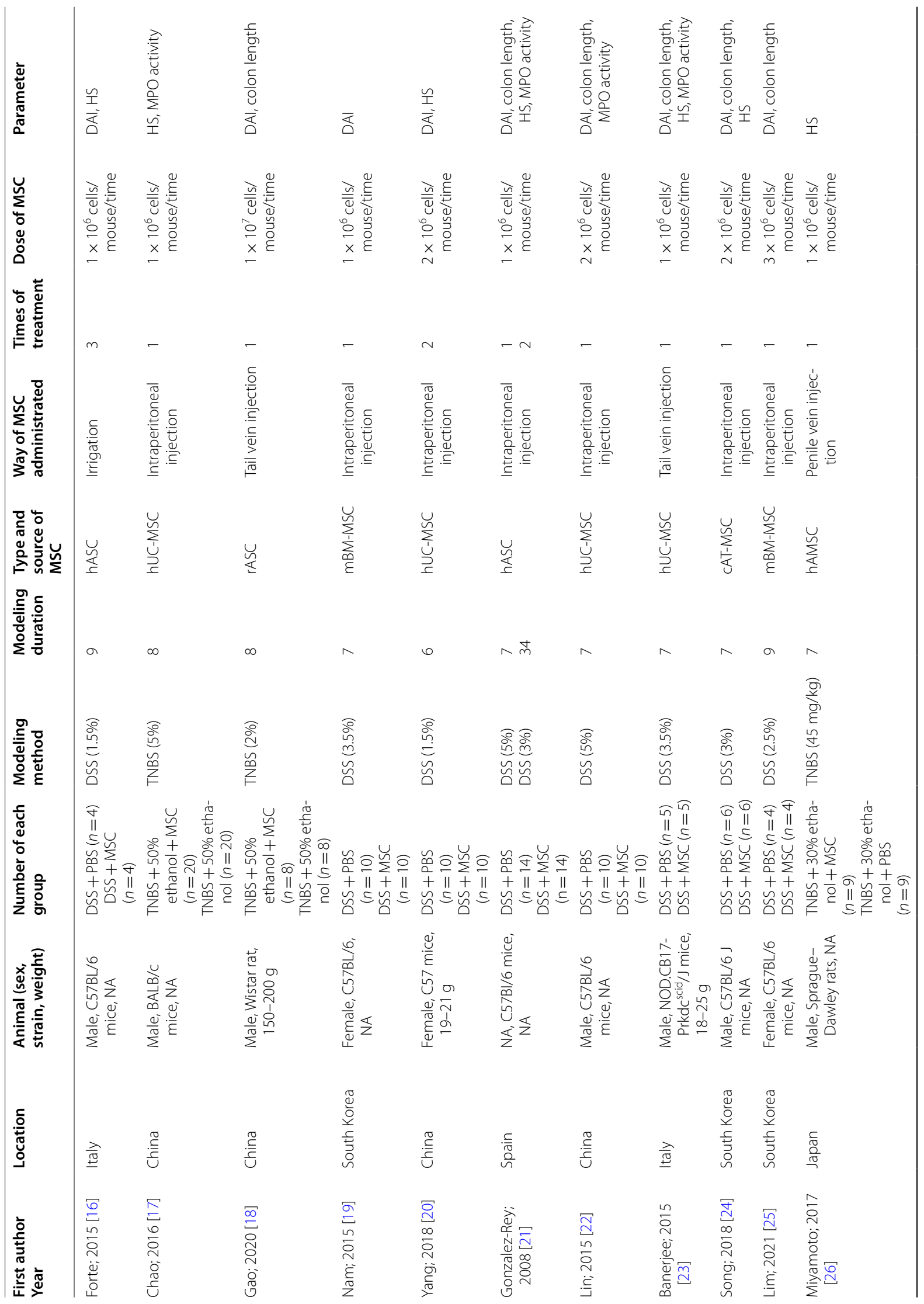




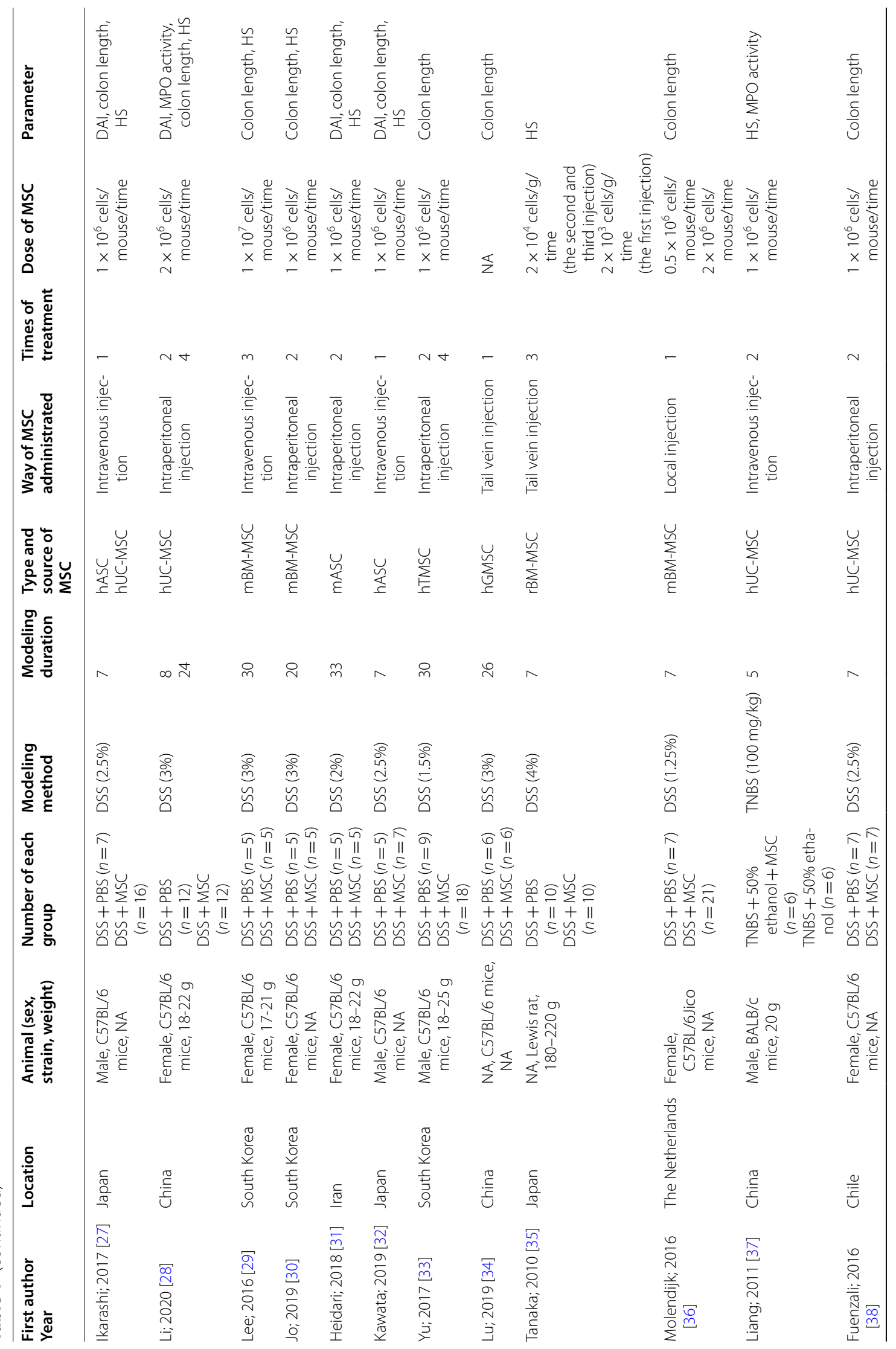




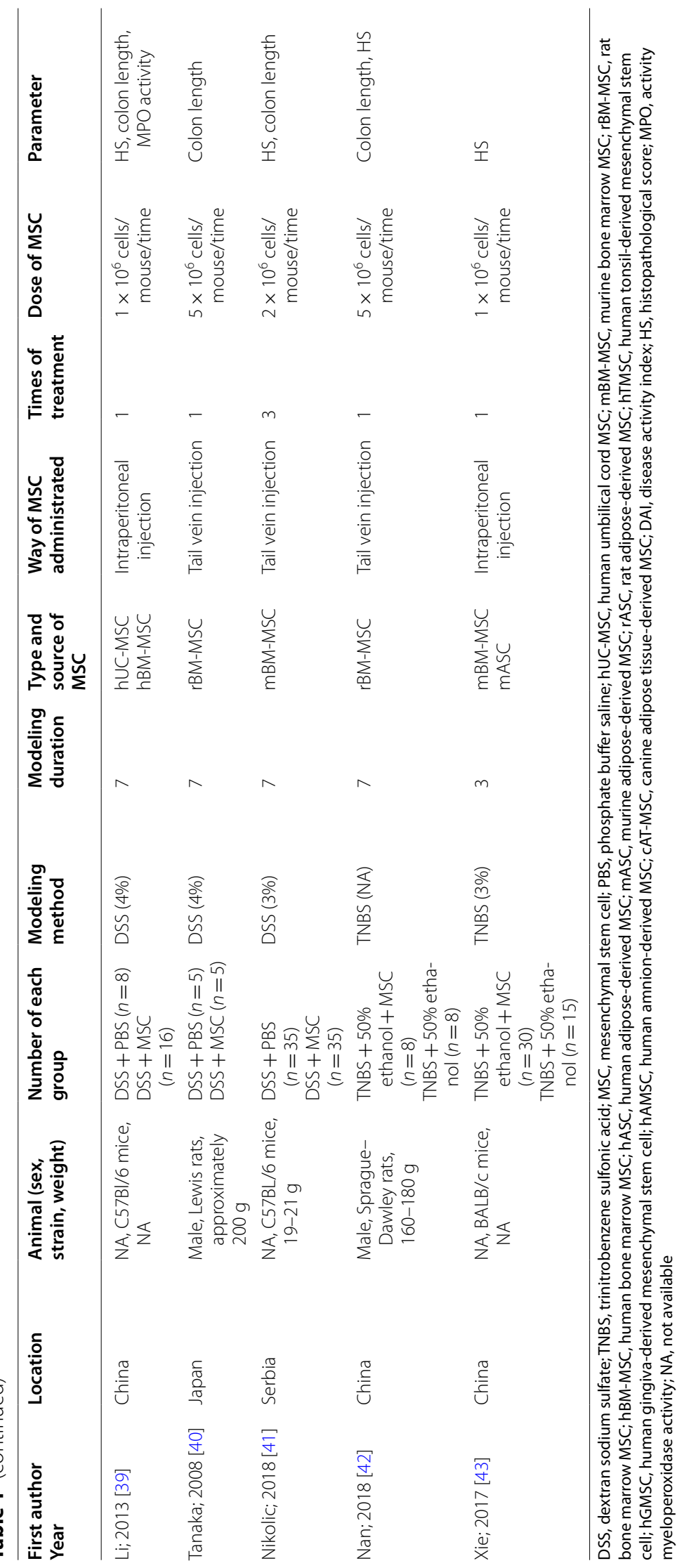




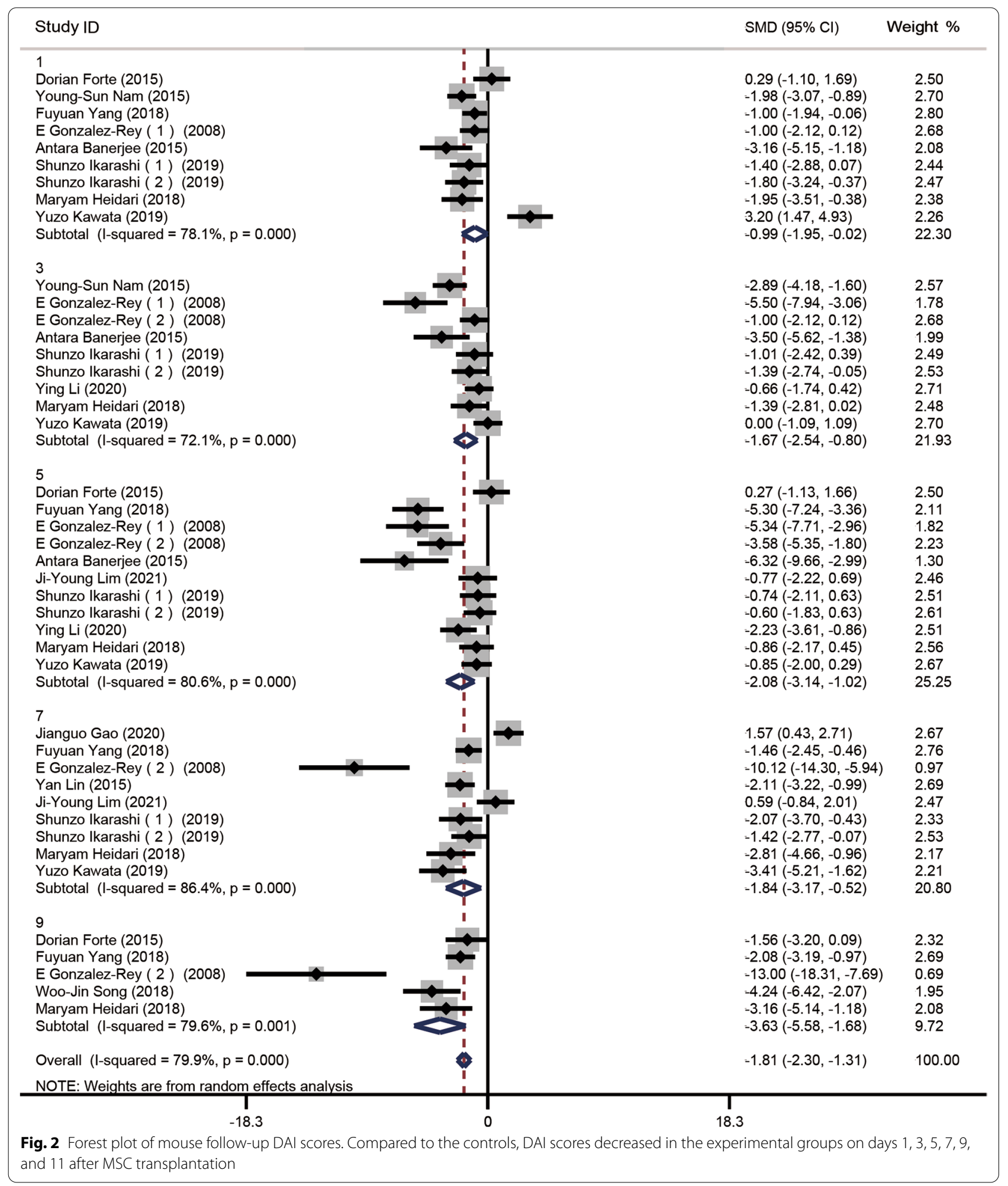




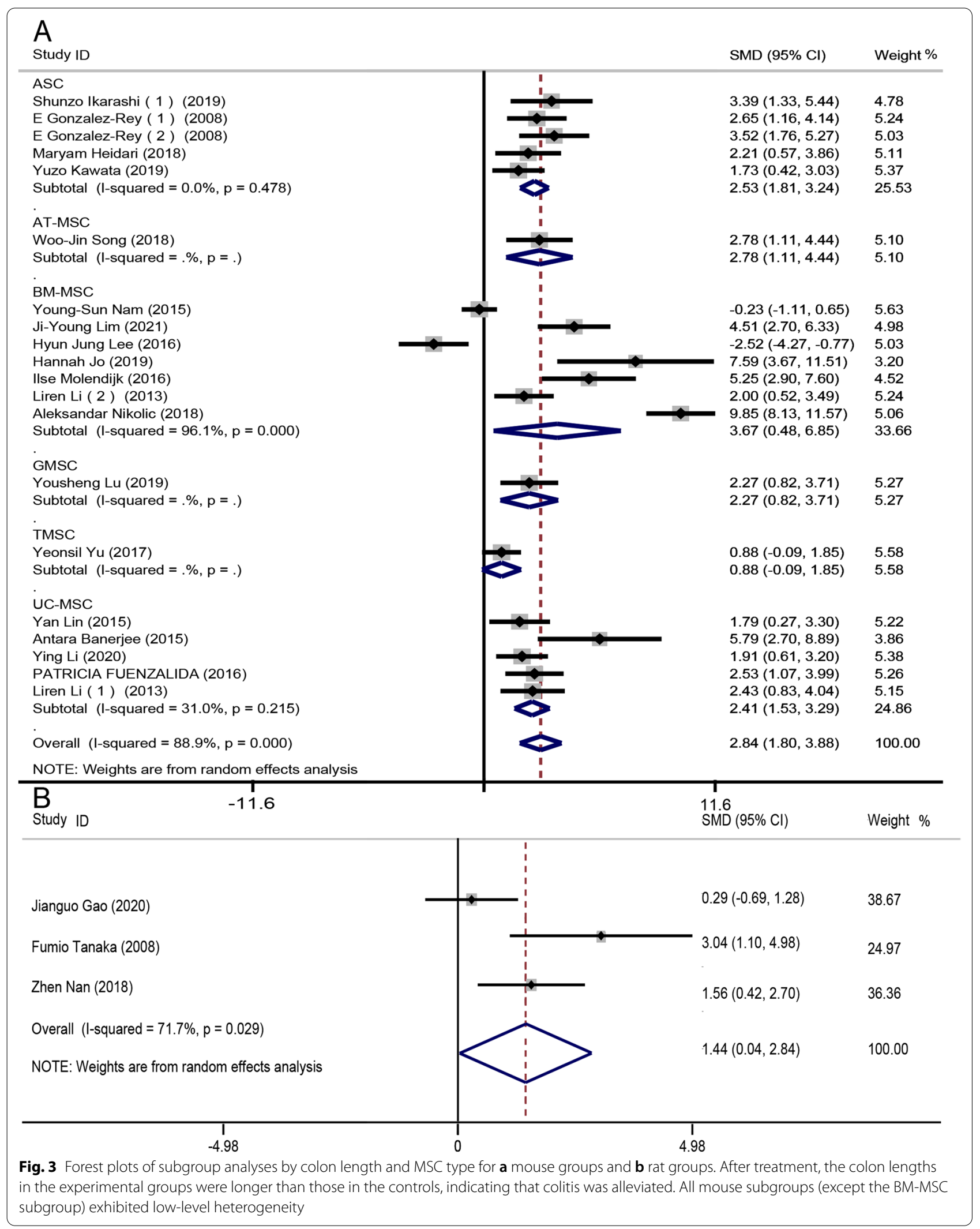




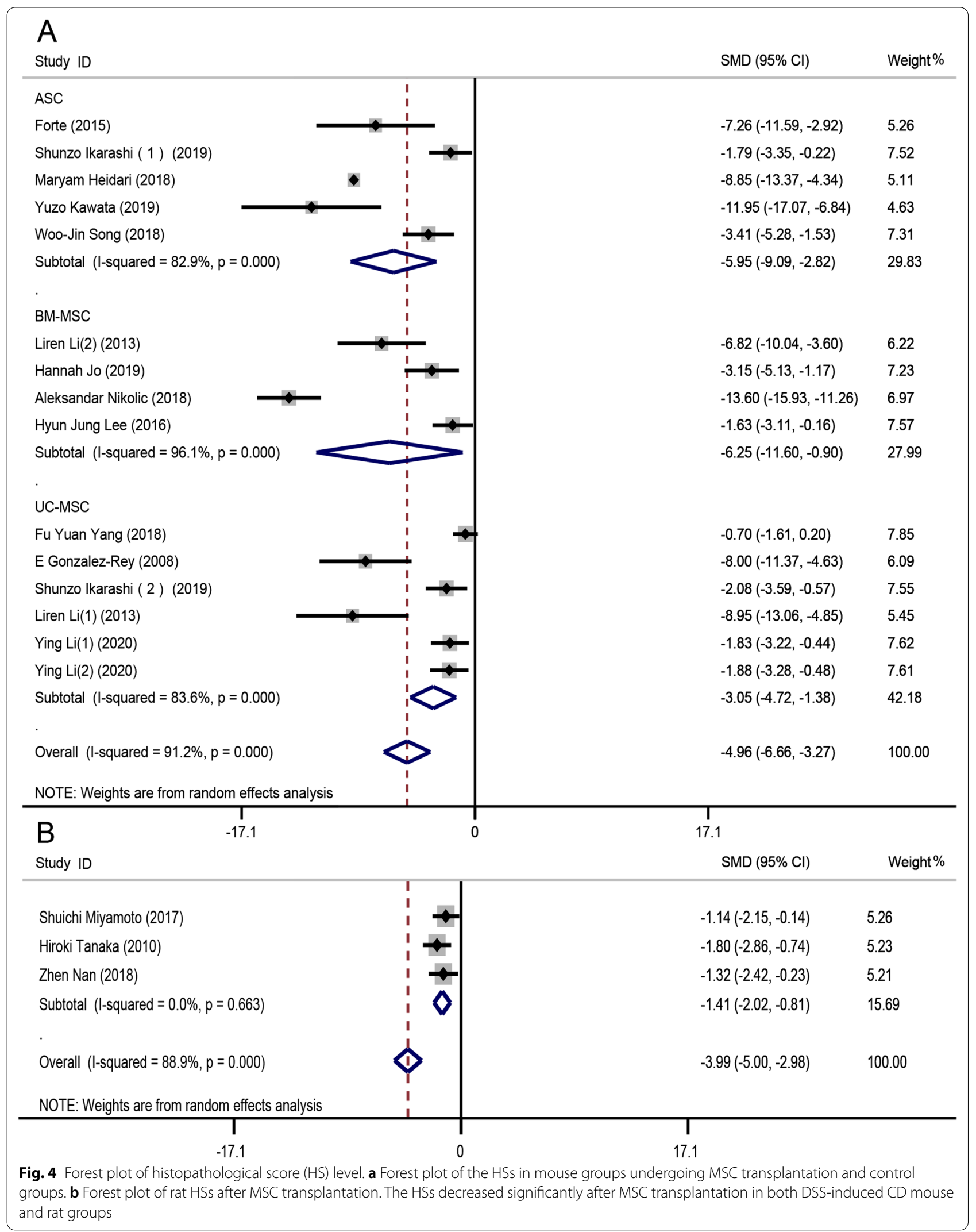




\section{Myeloperoxidase level}

Six studies [17, 21-23, 28] reported MPO levels $(n=102$ animals). The meta-analysis indicated that the MPO level in the treatment groups was significantly lower than that in the control groups (SMD-6.22, 95\% CI - 9.20 to $-3.32, I^{2}=90.8 \%, P=0.000$ ) (Additional file 1: Fig. $\mathrm{S7B})$. The level of heterogeneity could not be reduced by excluding any one or two studies.

\section{Cytokine level}

21 studies showed the level of cytokines before and after the treatment [16-19, 21, 22, 24-27, 29-33, 36, 37, 39, 40, $42,43]$. In both mRNA and protein level, there was a dramatic decrease in IL-6 [mRNA(GAPDH): SMD - 1.18, 95\% CI -1.77 to $-0.60, I^{2}=0, P=0.000$; protein (colon): SMD $-3.75,95 \% \mathrm{CI}-5.18$ to $\left.-2.33, I^{2}=77 \%, P=0.000\right]$, IL-17 [mRNA(GAPDH): SMD - 0.66, 95\% CI -1.21 to $-0.11, I^{2}=0, P=0.000$; protein (colon): $\mathrm{SMD}-3.51$, 95\% CI -5.44 to $\left.-1.58, I^{2}=76 \%, P=0.000\right]$ and TNF- $\alpha$ [mRNA (GAPDH): SMD $-0.88,95 \% \mathrm{CI}-1.54$ to -0.23 , $I^{2}=34.3 \%, P=0.000$; protein (colon): $\mathrm{SMD}-2.24,95 \%$ $\mathrm{CI}-3.04$ to $\left.-1.43, I^{2}=5 \%, P=0.000\right]$ compared with the control group (Additional file 1: Fig. S8 and Fig, S9). IL-10, which is an anti-inflammatory cytokine, increased after the treatment in mRNA level [mRNA ( $\beta$-actin): SMD 4.30, 95\% CI 2.17-6.43, $\left.I^{2}=84.7 \%, \quad P=0.000\right]$ (Additional file 1: Fig. S8-S9).

\section{Human studies}

\section{Description and quality assessment}

We evaluated 18 human studies including 360 patients. The clinical characteristics, results of quality evaluation, and patient demographics are summarized in Table 2.

\section{Crohn's disease activity index}

Eleven $[44,46-48,50,53-55,57,59,60]$ of the 18 studies included CDAI scores, which were significantly lower in the transplantation groups compared to the control groups $(\mathrm{SMD}-2.10,95 \% \mathrm{CI}-2.88$ to -1.32 , $\left.I^{2}=85.8 \%, P=0.000\right)$. Subgroup analysis by stem cell type revealed that HSCs $(\mathrm{SMD}-3.70,95 \% \mathrm{CI}-5.14$ to -2.25 , $\left.I^{2}=83.8 \%, P=0.000\right)$ afforded more stable outcomes than did MSCs (SMD-1.07, 95\% CI-1.56 to -0.59, $I^{2}=47.7 \%, P=0.000$ ) (Fig. 5). After excluding the studies of Oyama et al. [60] and Cassinotti et al. [57], $I^{2}$ decreased from $83.6 \%$ to $64.6 \%$ (Additional file 1 : Fig. S10A). In addition, the subgroup analysis by the source of stem cells indicated that the effect of autologous stem cells (SMD $-2.42,95 \% \mathrm{CI}-3.51$ to $\left.-1.33, I^{2}=88 \%, P=0.000\right)$ was better than the allogeneic stem cells (SMD -1.48 , $95 \% \mathrm{CI}-2.41$ to $-0.55, I^{2}=62.9 \%, P=0.000$ ) (Additional file 1: Fig. S10B). The stem cells were injected for different times in the studies we evaluated. In order to find the better treatment times, we did another subgroup analysis focus on the times of treatment. The result showed that the CDAI score of groups injected once (SMD - 2.96, $95 \% \mathrm{CI}-4.19$ to $\left.-1.73, I^{2}=85.9 \%, P=0.000\right)$ decreased more than other groups which was injected stem cells twice or fourth times (Additional file 1: Fig. S11).

\section{Remission rates}

Clinically, a CDAI $<150$ is defined as indicating remission. Fourteen studies [44, 45, 49-52, 54-61] reported the numbers of patients in remission after treatment. The remission rates at $1,3,6,12,24$, and 36 months after transplantation were $43 \%$ (95\% CI $0.12-0.76, I^{2}=85.09 \%$, $P=0.000$ ), 68\% (95\% CI 0.19-1, $\left.I^{2}=84.78 \%, P=0.000\right)$, $73 \%$ (95\% CI $\left.0.51-0.91, I^{2}=66.6 \%, P=0.000\right), 54 \%$ (95\% CI $\left.0.22-0.85, I^{2}=92.96 \%, P=0.000\right), 52 \%$ (95\% CI $0.37-$ $\left.0.66, I^{2}=22.18 \%, P=0.000\right)$, and $43 \%$ (95\% CI 0.22-0.65, $I^{2}=65.44 \%, P=0.000$ ), respectively (Fig. 6).

\section{Endoscopic sore}

In clinical, CD-EIS and SES-CD were always used to access endoscopic activity of CD patients. Three studies $[44,51,54]$ reported CD-EIS data, and another three studies [48, 54, 57] used SES-CD to access the endoscopic remission. The CD-EIS scores for the cell transplantation groups were lower than the pretreatment scores (SMD - 3.40, 95\% CI -6.75 to $-0.05, I^{2}=96 \%$, $P=0.000)$. In the same way, the SES-CD score of people who received stem cell treatment reduced compared with the score before treatment (SMD - 1.71, 95\% CI - 2.61 to $-0.82, I^{2}=55.4 \%, P=0.000$ ) (Fig. $\left.7 \mathrm{a}\right)$.

\section{Quality of life}

The IBDQ is always used to assess the quality of life of CD patients. Higher score means better quality of life. Four studies [48, 53, 54, 57] provided such data. After transplantation, the quality of life improved (SMD 1.33, 95\% CI $\left.0.89-1.77, I^{2}=17.3 \%, P=0.305\right)$. The subgroup analysis showed that the groups injected HSC (SMD 1.37, 95\% CI $\left.0.70-2.03, I^{2}=44.2 \%, P=0.000\right)$ had a higher IBDQ score than the groups received BM-MSC treatment (Additional file 1: Fig. S12A). In addition, it was indicated that after the therapy for 12 months, the IBDQ score increased compared with the score accessed after the treatment less than 6 months (Fig. 7b).

\section{Laboratory tests}

CRP levels are acutely elevated during infection or inflammation. Five studies [53-56, 60] reported CRP data; the levels did not differ greatly before and after treatment (SMD-0.06, 95\% CI -0.39 to $0.27, I^{2}=0$, $P=0.988$ ) (Additional file 1: Fig. S12B). 


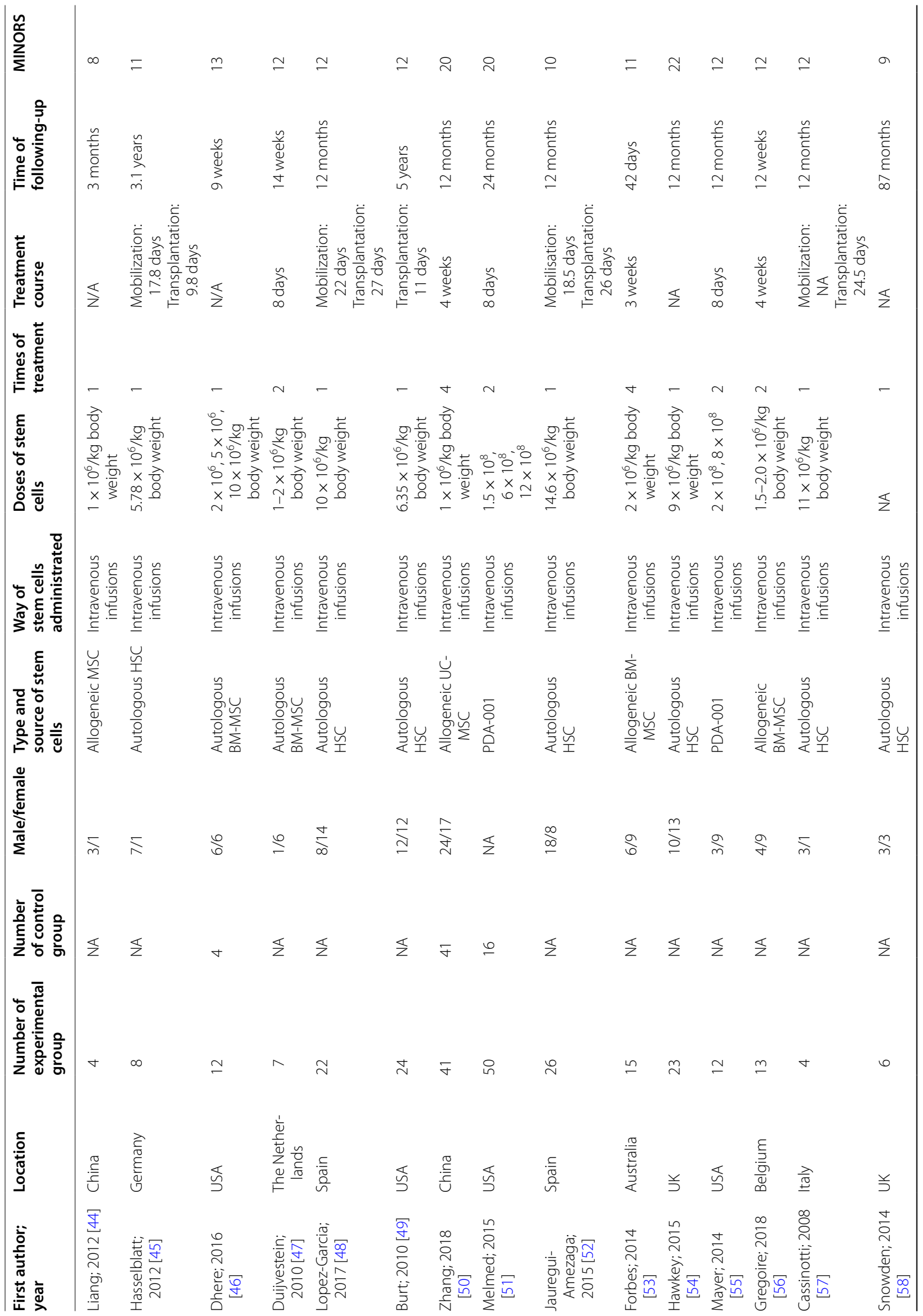




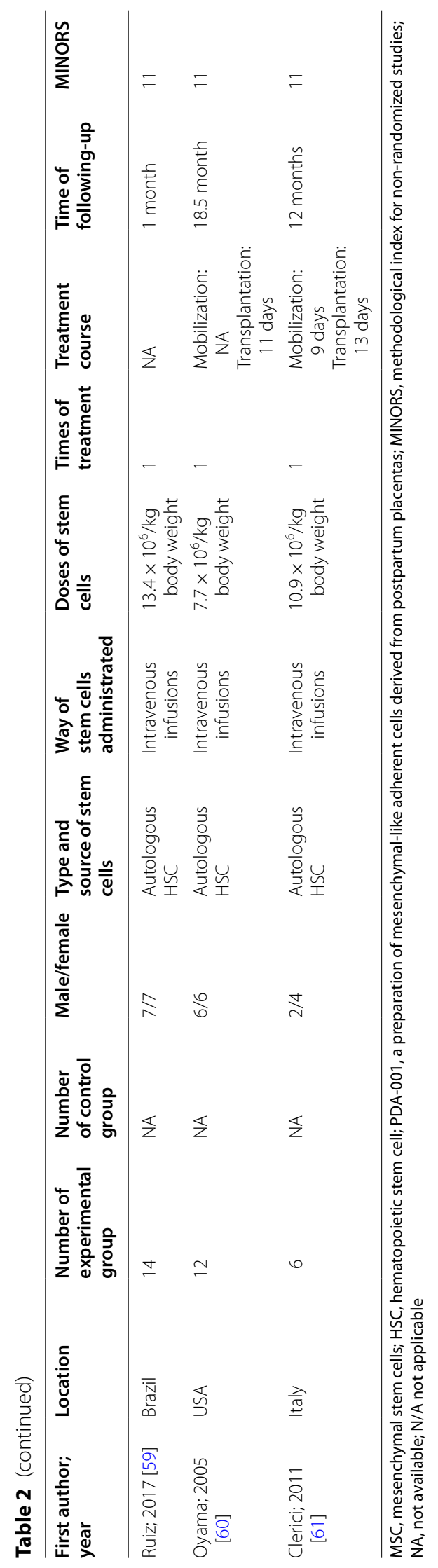




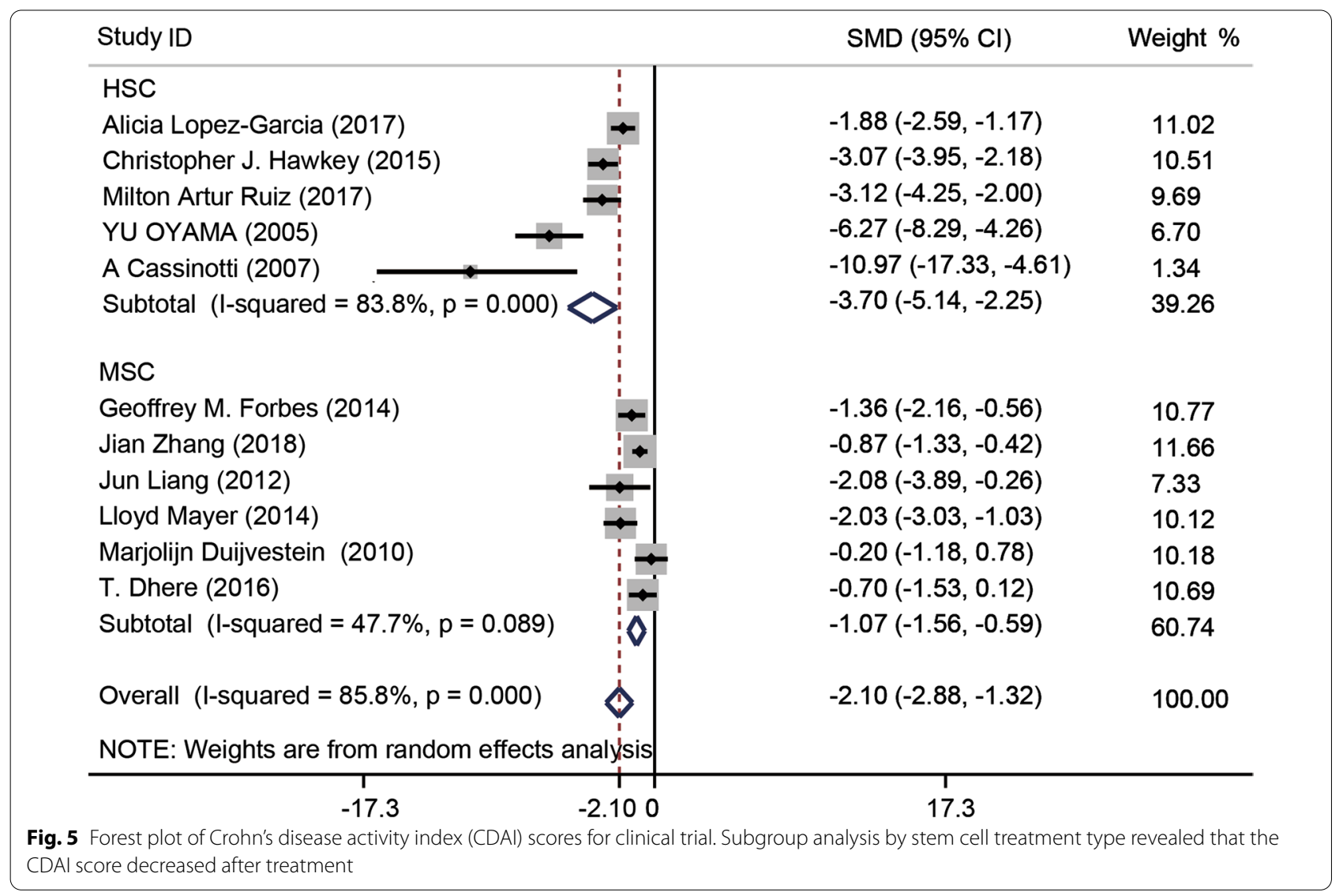

\section{Adverse events, complications and recurrence}

430 cases of adverse effects were reported in 18 studies, and there were 3 studies $[46,50,54]$ showing the data about the number of the adverse events in both experimental groups and placebo groups. The heterogeneity was low across each trial $\left(I^{2}=45.8 \%, P=0.16\right)$ (Additional file 1: Fig. S12C). Common adverse events included viral infections, fever, neutropenia, adrenal insufficiency, and headache. After HSC transplantation, the main adverse reaction was infection during HSC mobilization and regulation. Two patients died of cytomegalovirus infections. Thus, during HSC mobilization, the drug doses prescribed and patient care are critical. In the MSC transplantation group, the main adverse reactions were fever and headache, which were mild and often selfhealing. One patient developed well-differentiated stage I sigmoid colon adenocarcinoma; active enteritis had discouraged exploratory endoscopy.

A total of 7 studies $(n=82)$ reported the recurrence data and relapses occurred in 29 patients. There was 10 relapsing within one year after the treatment, and the rest 3,15 and 1 patients presented clinical and/or endoscopic relapse after 12 months, 53.1 weeks and 15 months after transplant, respectively.

\section{Discussion}

$\mathrm{CD}$ is usually treated by addressing the symptoms. However, many patients relapse, and the preferred drugs can have very serious side effects. An effective and safe treatment is urgently required. We explored whether SCs could be used to treat CD in animals and human. SCs reduced intestinal inflammation, enhanced (endoscopically evaluated) mucosal healing, and improved the quality of life in $\mathrm{CD}$ patients. SC transplantation should be recommended in clinical practice.

After subgroup and sensitivity analyses, heterogeneity among studies remained very high, attributable to the injection method and model used as well as differences in stem cell types. Of 28 animal studies, 14 featured intraperitoneal injections, 7 tail vein injections, and the rest other injections. Two different mouse CD models (DSS and TNBS) were employed; DSS concentrations ranged from 1.25 to $5 \%(\mathrm{w} / \mathrm{v})$, and the model duration ranged from 3 to 34 days. Finally, SC donor age, health status, whether the cells were frozen, endpoints, and whether the cells came from the same species as the recipient may all impact the therapeutic effect. More high-quality clinical and animal trials are required. 


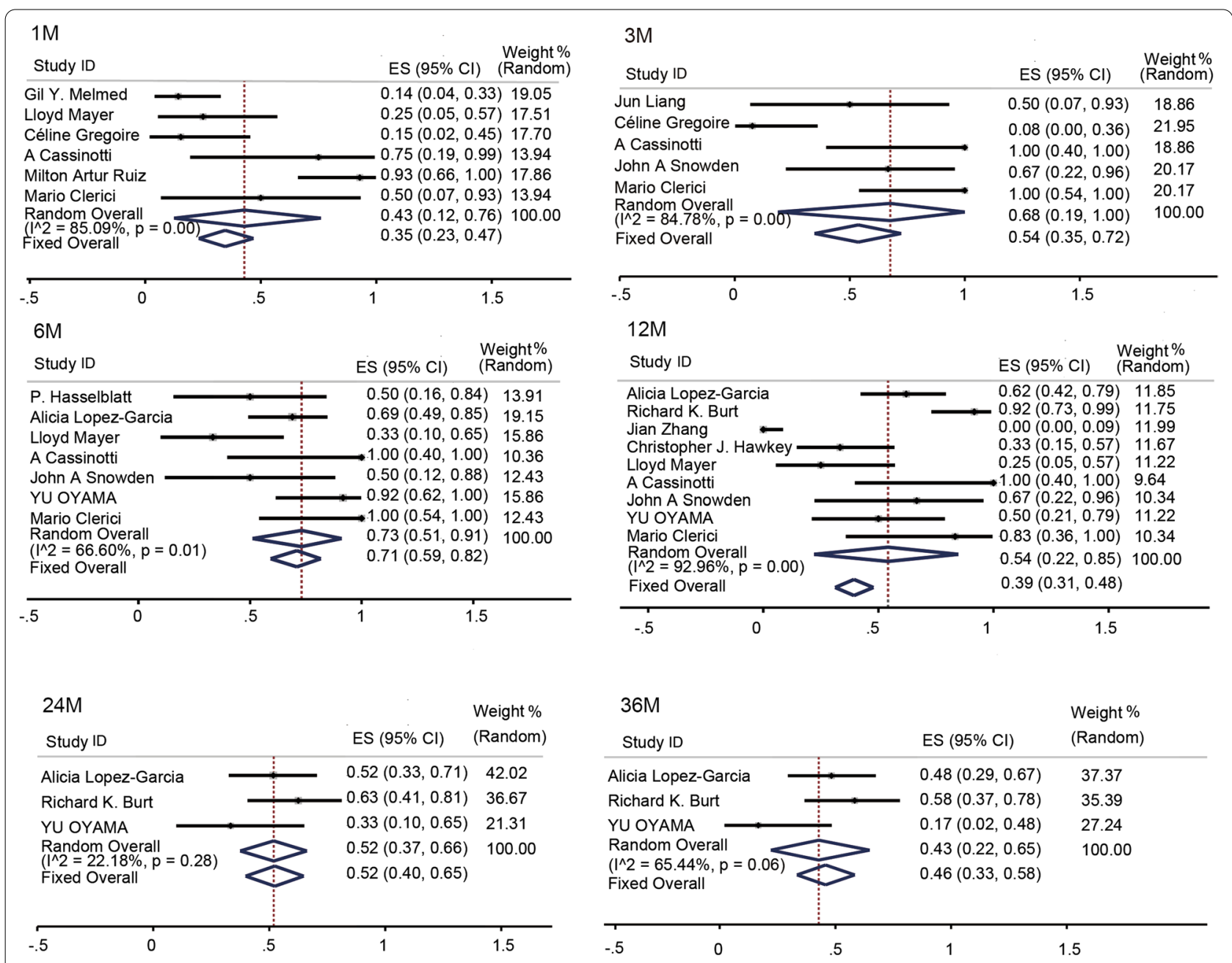

Fig. 6 Forest plots of subgroup remission rates by time. The remission rates at 1, 3, 5, 12, 24, and 36 months after st em cell therapy were 43\%, 68\%, $73 \%, 54 \%, 52 \%$, and $46 \%$, respectively, thus both high and stable

We compared the responses of animals with DSS- and TNBS-induced CD to MSC treatment. MSCs were therapeutic in both models, but more so in the DSS model. Similarly, in mice with CD, BM-MSCs had a stronger therapeutic effect than did other MSCs.

The safety of SC therapy requires attention. We found that the HSC treatment group was more prone to adverse reactions such as viral infections, which often accompany HSC mobilization and regulation. It is clear that CD patients are at higher risk of infection compared to those who undergo transplantation to treat cancer or other diseases that do not involve the intestinal tract. During SC mobilization, patient immunity is reduced and the risk of infection is higher. Therefore, patients should be carefully nursed during mobilization and reasonable drug levels should be prescribed to reduce the development of adverse reactions. To prevent complications in CD patients with perianal disease, it is advisable to perform drainage, implement strict hygiene measures for contact, and prescribe adequate antibiotic prophylaxis [62]. The implementation of such measures in recent studies dramatically improved safety [52]. MSCs derived from bone marrow or the umbilical cord were associated with lower risks of infection, and most side effects were mild and not associated with MSC injection. UC-MSCs are obtained easily and less invasively, as the donors are young [63], their cell status is good, and the immunogenicity is low. In summary, both treatment efficacy and the type of therapy require attention.

However, the pathogenesis of $C D$ is complex and remains poorly understood [64]. The western diet has been suggested to contribute to the rising incidence of inflammatory bowel diseases. A recent study reported that the interaction between fructose and its transporter, GLUT5, could shape the colonic microbiota and then impact the severity of CD [65]. Another studies 


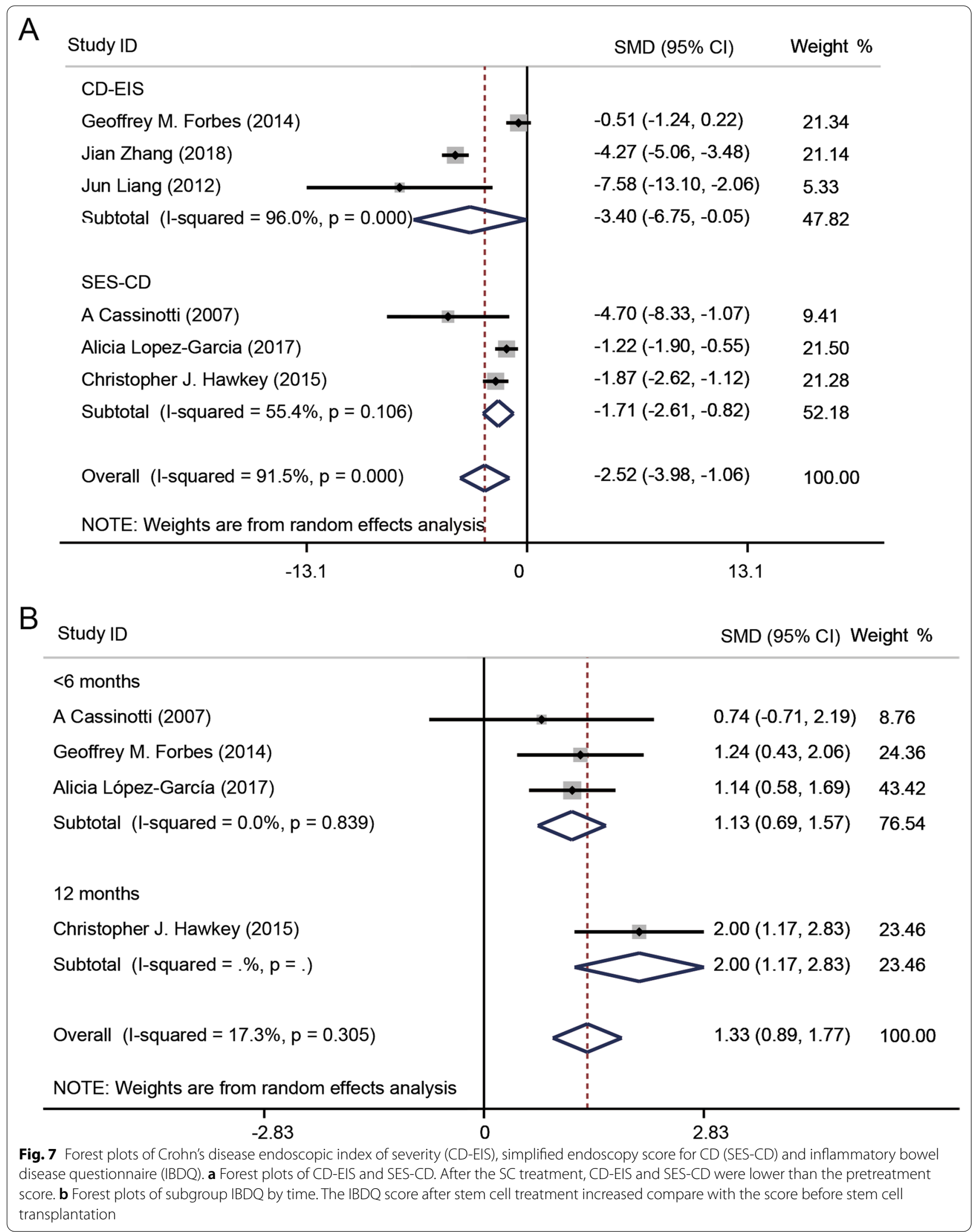


showed that serum exosomes could circulate into the intestinal mucosa, regulating macrophage activation and epithelial barrier function to aggravate colitis [66]. Additionally, immune system disorders are clearly in play. Researchers found that advanced oxidation protein products (AOPPs), mainly deposited in macrophages of $\mathrm{CD}$ patients, induced macrophage's lysosomal dysfunction and M1 polarization, which could lead to the intestinal inflammation [67]. $\mathrm{CD}^{+} \mathrm{T}$ cells are involved in $\mathrm{CD}$ initiation and development, and Th1 or Th2 cells are involved in inflammation [68-70]. The levels of mucosal $\mathrm{CD}^{+}{ }^{+}$helper $\mathrm{T}$ cells that secrete effector cytokines such as TNF- $\alpha$ and IFN- $\gamma$ are abnormally high in the guts of $\mathrm{CD}$ patients [71]. Immunomodulatory mechanisms are constrained in such patients. For example, the numbers of immunosuppressive regulatory $\mathrm{T}$ cells are significantly reduced in CD patients [72]. The development and maintenance of intestinal inflammation in $\mathrm{CD}$ patients probably reflect an imbalance between pro- and antiinflammatory mechanisms. MSC secrete growth factors, exosomes, cytokines, and metabolites that inhibit inflammation, restore the intestinal mucosal barrier, and are protective. HSCs regenerate self-tolerant lymphocytes in non-inflammatory environments after conditioning that induces an immediate immune cease-fire [73].

Besides MSCs, cytokines and extracellular vehicles (EVs) which are released by MSC also have the therapeutic effect on $C D$. Because of the low immunogenic profile, which decreases the potential for cell rejection and graft-versus-host-disease, more and more studies begin to focus on the paracrine action of MSC. Neda Heidari et al. [74] and Ju-Hyun An et al. [75] showed that exosomes and prostaglandin E2, isolated from adiposederived MSC (ASC), could regulate the Treg population and improve acute colitis inflammation induced by DSS.

Stem cell therapy is not only useful for refractory luminal $C D$, but also shows good effect on the complications of CD [76]. About 20\% of CD patients develop to perianal fistulizing Crohn's disease (pCD), and it is easy to recur [77]. Cx601 (darvadstrocel) is a suspension of human allogenic ASC and its indication is the complex pCD [78]. A lot of clinical trials have proved the effectiveness of treatment for $\mathrm{pCD}$ [79-81]. The strong evidence was mainly from a randomized, double-blind, placebocontrolled, multicenter trial (ADMIRE-CD), which indicated that patients who received ASC transplantation had a higher rate of combined remission than the placebo group.

Our work had certain limitations. First, most human studies were single-arm trials with few patients and thus of low quality. Second, CD-EIS, SES-CD data (which reflect endoscopic mucosal healing), IBDQ scores (which reflect the quality of life) and pathological grading were lacked in some studies. Any role for SCs in CD alleviation requires further evaluation.

\section{Conclusion}

We carefully reviewed whether SC therapy improved CD. Stem cell transplantation reduced gut inflammation and improved the quality of life. However, more high-quality randomized controlled clinical trials and basic research are required.

\begin{abstract}
Abbreviations
CD: Crohn's disease; SMD: Standardized mean difference; ORs: Odds ratios; Cl: Confidence interval; SD: Standard deviation; PRISMA-P: Preferred reporting items for systematic review and meta-analysis protocols; DSS: Dextran sulfate sodium; TNBS: Trinitrobenzene sulfonic acid; DAl: Disease activity index; HS: Histopathological score; MPO: Myeloperoxidase; MSC: Mesenchymal stem cell; BM-MSC: Bone marrow mesenchymal stem cell; UC-MSC: Umbilical cord mesenchymal stem cell; ASC: Adipose-derived mesenchymal stem cell; HSC: Hematopoietic stem cell; IBD: Inflammatory bowel disease; CS: Corticosteroids; CDAl: Crohn's disease activity index; CRP: C-reactive protein; IBDQ: Inflammatory bowel disease questionnaire; CD-EIS: CD endoscopic index of severity; RCT: Randomized clinical trial; CMV: Cytomegalovirus; SC: Stem cell; SES-CD: Simplified endoscopy score for $C D$.
\end{abstract}

\section{Supplementary Information}

The online version contains supplementary material available at https://doi. org/10.1186/s13287-021-02533-0.

Additional file 1: Table S1: The study quality of animal studies; Figure S1: Publication bias of the outcomes: histopathological score, colon length, MPO activity, CDAl; Figure S2: The sensitivity analysis about DAI scores of the 1st day and the 3rd day after the treatment; Figure S3: The sensitivity analysis about DAI score of the 7th day and the 9th day after the treatment; Figure S4: The sensitivity analysis about colon length in the rat group; Figure S5: The subgroup analysis of histopathological score in the mouse group about modeling methods; Figure S6: The sensitivity analysis of histopathological score in the DSS mouse model group; Figure S7: The sensitivity analysis of histopathological score in the TNBS mouse model and the forest plot about the level of MPO activity of animal studies. Figure S8: The forest plot of IL-6, and IL-17 in the both mRNA and protein levels. Figure S9: The forest plot of IL-10 and TNF-a in the both mRNA and protein levels; Figure S10: The sensitivity analysis of HSC subgroup and subgroup analysis of CDAl score of different stem cell sources. Figure S11: The sensitivity analysis of CDAl scores of different treatment times; Figure S12: The subgroup analysis of IBDQ scores of different stem cell types, the forest plots of CRP and the adverse events happened in the experimental and placebo groups.

\section{Authors' contributions}

RW searched the databases, extracted the data, and wrote the manuscript. QY screened and evaluated the quality of evidence and extracted the data. WC, FG, JY, JW, and PL participated in the design of the study and performed the statistical analysis. HC contributed to the study design and the manuscript writing. All authors read and approved the final manuscript.

\section{Funding}

The present study was supported by Stem Cell and Translational Research from National Key Research and Development Program of China (No. 2020YFA0113003).

Availability of data and materials

All data generated or analyzed during this study are included in this article. 


\section{Declarations}

Ethics approval and consent to participate

Not applicable.

\section{Consent for publication}

Not applicable.

\section{Competing interests}

The authors declare no competing interests.

\section{Author details}

${ }^{1}$ State Key Laboratory for the Diagnosis and Treatment of Infectious Diseases, Collaborative Innovation Center for Diagnosis and Treatment of Infectious Diseases, The First Affiliated Hospital, Zhejiang University School of Medicine, 79 Qingchun Rd., Hangzhou City 310003, China. ${ }^{2}$ National Clinical Research Center for Infectious Diseases, 79 Qingchun Rd., Hangzhou City 310003, China. ${ }^{3}$ Zhejiang Provincial Key Laboratory for Diagnosis and Treatment of Aging and Physic-Chemical Injury Diseases, 79 Qingchun Rd., Hangzhou City 310003, China.

Received: 6 June 2021 Accepted: 2 August 2021

Published online: 18 August 2021

\section{References}

1. Baumgart DC, Sandborn WJ. Crohn`s disease. Lancet. 2012;380:1590-616.

2. De Souza HS, Fiocchi C. Immunopathogenesis of IBD: current state of the art. Nat Rev Gastroenterol Hepatol. 2016;13:13-27.

3. Loftus EV. Clinical epidemiology of inflammatory bowel disease: incidence, prevalence, and environmental influences. Gastroenterology. 2004;126:1504-17.

4. Molodecky NA, Soon S, Rabi DM, Ghali WA, Ferris M, Chernof G, et al. Increasing incidence and prevalence of the inflammatory bowel diseases with time, based on systematic review. Gastroenterology. 2012;142:46-54.

5. Abraham C, Cho JH. Inflammatory bowel disease. N Engl J Med. 2009:361:2066-78.

6. Van Assche G. Immunogenicity of anti-TNF antibodies: has the veil been lifted? Gut. 2011;60(3):285-6.

7. Mowat C, Cole A, Windsor A, Ahmad T, Arnott I, Driscoll R, et al. Guidelines for the management of inflammatory bowel disease in adults. Gut. 2011;60(5):571-607.

8. Liu H, Chen Y, Yin G, Xie Q. Therapeutic prospects of MicroRNAs carried by mesenchymal stem cells-derived extracellular vesicles in autoimmune diseases. Life Sci. 2021;5:119458.

9. Garcia-Olmo D, Herreros D, Pascual I, Pascual JA, Del-Valle E, Zorrilla J, et al. Expanded adipose-derived stem cells for the treatment of complex perianal fistula: a phase II clinical trial. Dis Colon Rectum. 2009:52:79-86.

10. Panés J, García-Olmo D, Van Assche G, Colombel JF, Reinisch W, Baumgart $D C$, et al. Expanded allogeneic adipose-derived mesenchymal stem cells (Cx601) for complex perianal fistulas in Crohn's disease: a phase 3 randomised, doubleblind controlled trial. Lancet. 2016;388:1281-90.

11. Swart JF, Delemarre EM, van Wijk F, Boelens JJ, Kuball J, van Laar JM, et al. Haematopoietic stem cell transplantation for autoimmune diseases. Nat Rev Rheumatol. 2017:13(4):244-56.

12. Hooijmans CR, Rovers MM, de Vries RB, Leenaars M, Ritskes-Hoitinga M, Langendam MW. SYRCLE's risk of bias tool for animal studies. BMC Med Res Methodol. 2014;26(14):43.

13. Slim K, Nini E, Forestier D, Kwiatkowski F, Panis Y, Chipponi J. Methodological index for non-randomized studies (minors): development and validation of a new instrument. ANZ J Surg. 2003;73(9):712-6.

14. Shamseer L, Moher D, Clarke M, Ghersi D, Liberati A, Petticrew M, et al. PRISMA-P group: preferred reporting items for systematic review and meta-analysis protocols (PRISMA-P) 2015: elaboration and explanation. BMJ. 2015;350:g7647.

15. Wu XL, Tu Q, Faure G, Gallet P, Kohler C, Bittencourt MC. Diagnostic and prognostic value of circulating tumor cells in head and neck squamous cell carcinoma: a systematic review and meta-analysis. Sci Rep. 2016;2(6):20210.

16. Forte D, Ciciarello M, Valerii MC, De Fazio L, Cavazza E, Giordano R, et al. Human cord blood-derived platelet lysate enhances the therapeutic activity of adipose-derived mesenchymal stromal cells isolated from Crohn's disease patients in a mouse model of colitis. Stem Cell Res Ther. 2015;6(1):170.

17. Chao K, Zhang S, Qiu Y, Chen X, Zhang X, Cai C, et al. Human umbilical cord-derived mesenchymal stem cells protect against experimental colitis via CD5(+) B regulatory cells. Stem Cell Res Ther. 2016;7(1):109.

18. Gao JG, Yu MS, Zhang MM, Gu XW, Ren Y, Zhou XX, et al. Adipose-derived mesenchymal stem cells alleviate TNBS-induced colitis in rats by influencing intestinal epithelial cell regeneration, Wnt signaling, and T cell immunity. World J Gastroenterol. 2020;26(26):3750-66.

19. Nam YS, Kim N, Im KI, Lim JY, Lee ES, Cho SG. Negative impact of bonemarrow-derived mesenchymal stem cells on dextran sulfate sodiuminduced colitis. World J Gastroenterol. 2015;21(7):2030-9.

20. Yang FY, Chen $R$, Zhang $X$, Huang $B$, Tsang LL, Li X, et al. Preconditioning enhances the therapeutic effects of mesenchymal stem cells on colitis through PGE2-mediated T-cell modulation. Cell Transplant. 2018;27(9):1352-67.

21. Gonzalez-Rey E, Anderson P, González MA, Rico L, Büscher D, Delgado M. Human adult stem cells derived from adipose tissue protect against experimental colitis and sepsis. Gut. 2009;58(7):929-39.

22. Lin Y, Lin L, Wang Q, Jin Y, Zhang Y, Cao Y, et al. Transplantation of human umbilical mesenchymal stem cells attenuates dextran sulfate sodiuminduced colitis in mice. Clin Exp Pharmacol Physiol. 2015:42(1):76-86. https://doi.org/10.1111/1440-1681.12321.

23. Banerjee A, Bizzaro D, Burra P, Di Liddo R, Pathak S, Arcidiacono D, et al. Umbilical cord mesenchymal stem cells modulate dextran sulfate sodium induced acute colitis in immunodeficient mice. Stem Cell Res Ther. 2015;6(1):79.

24. Song WJ, Li Q, Ryu MO, Ahn JO, Bhang DH, Jung YC, et al. TSG-6 released from intraperitoneally injected canine adipose tissue-derived mesenchymal stem cells ameliorate inflammatory bowel disease by inducing M2 macrophage switch in mice. Stem Cell Res Ther. 2018;9(1):91.

25. Lim JY, Kim BS, Ryu DB, Kim TW, Park G, Min CK. The therapeutic efficacy of mesenchymal stromal cells on experimental colitis was improved by the IFN- $\gamma$ and poly $(\mathrm{l}: \mathrm{C})$ priming through promoting the expression of indoleamine 2,3-dioxygenase. Stem Cell Res Ther. 2021;12(1):37.

26. Miyamoto S, Ohnishi S, Onishi R, Tsuchiya I, Hosono H, Katsurada T, et al. Therapeutic effects of human amnion-derived mesenchymal stem cell transplantation and conditioned medium enema in rats with trinitrobenzene sulfonic acid-induced colitis. Am J Transl Res. 2017;9(3):940-52.

27. Ikarashi S, Tsuchiya A, Kawata Y, Kojima Y, Watanabe T, Takeuchi S, et al. Effects of human adipose tissue-derived and umbilical cord tissuederived mesenchymal stem cells in a dextran sulfate sodium-induced mouse model. Biores Open Access. 2019;8(1):185-99.

28. Li Y, Ma K, Zhang L, Xu H, Zhang N. Human umbilical cord blood derivedmesenchymal stem cells alleviate dextran sulfate sodium-induced colitis by increasing regulatory T cells in mice. Front Cell Dev Biol. 2020;8:604021.

29. Lee HJ, Oh SH, Jang HW, Kwon JH, Lee KJ, Kim CH, et al. Long-term effects of bone marrow-derived mesenchymal stem cells in dextran sulfate sodium-induced murine chronic colitis. Gut Liver. 2016:10(3):412-9.

30. Jo H, Eom YW, Kim HS, Park HJ, Kim HM, Cho MY. Regulatory dendritic cells induced by mesenchymal stem cells ameliorate dextran sodium sulfate-induced chronic colitis in mice. Gut Liver. 2018;12(6):664-73.

31. Heidari M, Pouya S, Baghaei K, Aghdaei HA, Namaki S, Zali MR, et al. The immunomodulatory effects of adipose-derived mesenchymal stem cells and mesenchymal stem cells-conditioned medium in chronic colitis. J Cell Physiol. 2018;233(11):8754-66.

32. Kawata Y, Tsuchiya A, Seino S, Watanabe Y, Kojima Y, Ikarashi S, et al. Early injection of human adipose tissue-derived mesenchymal stem cell after inflammation ameliorates dextran sulfate sodium-induced colitis in mice through the induction of M2 macrophages and regulatory T cells. Cell Tissue Res. 2019;376(2):257-71.

33. Yu Y, Song EM, Lee KE, Joo YH, Kim SE, Moon CM, et al. Therapeutic potential of tonsil-derived mesenchymal stem cells in dextran sulfate sodiuminduced experimental murine colitis. PLOS ONE. 2017;12(8):e0183141. 
34. Lu Y, Xu Y, Zhang S, Gao J, Gan X, Zheng J, et al. Human gingiva-derived mesenchymal stem cells alleviate inflammatory bowel disease via IL-10 signalling-dependent modulation of immune cells. Scand J Immunol. 2019;90(3):e12751.

35. Tanaka H, Arimura Y, Yabana T, Goto A, Hosokawa M, Nagaishi K, et al. Myogenic lineage differentiated mesenchymal stem cells enhance recovery from dextran sulfate sodium-induced colitis in the rat. J Gastroenterol. 2011;46(2):143-52.

36. Molendijk I, Barnhoorn MC, de Jonge-Muller ES, Mieremet-Ooms MA, van der Reijden JJ, van der Helm D, et al. Intraluminal injection of mesenchymal stromal cells in spheroids attenuates experimental colitis. J Crohns Colitis. 2016;10(8):953-64.

37. Liang L, Dong C, Chen X, Fang Z, Xu J, Liu M, et al. Human umbilical cord mesenchymal stem cells ameliorate mice trinitrobenzene sulfonic acid (TNBS)-induced colitis. Cell Transplant. 2011;20(9):1395-408.

38. Fuenzalida P, Kurte M, Fernández-O'ryan C, Ibañez C, Gauthier-Abeliuk $M$, Vega-Letter AM, et al. Toll-like receptor 3 pre-conditioning increases the therapeutic efficacy of umbilical cord mesenchymal stromal cells in a dextran sulfate sodium-induced colitis model. Cytotherapy. 2016;18(5):630-41.

39. Li L, Liu S, Xu Y, Zhang A, Jiang J, Tan W, et al. Human umbilical cordderived mesenchymal stem cells downregulate inflammatory responses by shifting the Treg/Th17 profile in experimental colitis. Pharmacology. 2013;92(5-6):257-64.

40. Tanaka F, Tominaga K, Ochi M, Tanigawa T, Watanabe T, Fujiwara Y, et al. Exogenous administration of mesenchymal stem cells ameliorates dextran sulfate sodium-induced colitis via anti-inflammatory action in damaged tissue in rats. Life Sci. 2008;83(23-24):771-9.

41. Nikolic A, Simovic Markovic B, Gazdic M, Randall Harrell C, Fellabaum C, Jovicic N, et al. Intraperitoneal administration of mesenchymal stem cells ameliorates acute dextran sulfate sodium-induced colitis by suppressing dendritic cells. Biomed Pharmacother. 2018;100:426-32.

42. Nan Z, Fan H, Tang Q, Zhang M, Xu M, Chen Q, et al. Dual expression of CXCR4 and IL-35 enhances the therapeutic effects of BMSCs on TNBSinduced colitis in rats through expansion of Tregs and suppression of Th17 cells. Biochem Biophys Res Commun. 2018;499(4):727-34.

43. Xie M, Qin H, Luo Q, He X, He X, Lan P, et al. Comparison of adiposederived and bone marrow mesenchymal stromal cells in a murine model of Crohn's disease. Dig Dis Sci. 2017;62(1):115-23.

44. Liang J, Zhang $H$, Wang D, Feng $X$, Wang $H$, Hua B, et al. Allogeneic mesenchymal stem cell transplantation in seven patients with refractory inflammatory bowel disease. Gut. 2012;61(3):468-9.

45. Hasselblatt P, Drognitz K, Potthoff K, Bertz H, Kruis W, Schmidt C, et al. Remission of refractory Crohn's disease by high-dose cyclophosphamide and autologous peripheral blood stem cell transplantation. Aliment Pharmacol Ther. 2012;36(8):725-35.

46. Dhere T, Copland I, Garcia M, Chiang KY, Chinnadurai R, Prasad M, et al. The safety of autologous and metabolically fit bone marrow mesenchymal stromal cells in medically refractory Crohn's disease: a phase 1 trial with three doses. Aliment Pharmacol Ther. 2016;44(5):471-81.

47. Duijvestein $M$, Vos $A C$, Roelofs $H$, Wildenberg ME, Wendrich BB, Verspaget $H W$, et al. Autologous bone marrow-derived mesenchymal stromal cell treatment for refractory luminal Crohn's disease: results of a phase I study. Gut. 2010;59(12):1662-9.

48. López-García A, Rovira M, Jauregui-Amezaga A, Marín P, Barastegui R, Salas A, et al. Autologous haematopoietic stem cell transplantation for refractory Crohn's disease: efficacy in a single-centre cohort. J Crohns Colitis. 2017;11(10):1161-8.

49. Burt RK, Craig RM, Milanetti F, Quigley K, Gozdziak P, Bucha J, et al. Autologous nonmyeloablative hematopoietic stem cell transplantation in patients with severe anti-TNF refractory Crohn disease: long-term followup. Blood. 2010;116(26):6123-32.

50. Zhang J, Lv S, Liu X, Song B, Shi L. Umbilical cord mesenchymal stem cell treatment for Crohn's disease: a randomized controlled clinical trial. Gut Liver. 2018;12(1):73-8.

51. Melmed GY, Pandak WM, Casey K, Abraham B, Valentine J, Schwartz $D$, et al. Human placenta-derived cells (PDA-001) for the treatment of moderate-to-severe crohn's disease: a phase 1b/2a study. Inflamm Bowel Dis. 2015;21(8):1809-16.
52. Jauregui-Amezaga A, Rovira M, Marín P, Salas A, Pinó-Donnay S, Feu F, et al. Improving safety of autologous haematopoietic stem cell transplantation in patients with Crohn's disease. Gut. 2016;65(9):1456-62.

53. Forbes GM, Sturm MJ, Leong RW, Sparrow MP, Segarajasingam D, Cummins AG, et al. A phase 2 study of allogeneic mesenchymal stromal cells for luminal Crohn's disease refractory to biologic therapy. Clin Gastroenterol Hepatol. 2014;12(1):64-71.

54. Hawkey CJ, Allez M, Clark MM, Labopin M, Lindsay JO, Ricart E, et al. Autologous hematopoetic stem cell transplantation for refractory Crohn disease: a randomized clinical trial. JAMA. 2015;314(23):2524-34.

55. Mayer L, Pandak WM, Melmed GY, Hanauer SB, Johnson K, Payne D, et al. Safety and tolerability of human placenta-derived cells (PDA001) in treatment-resistant crohn's disease: a phase 1 study. Inflamm Bowel Dis. 2013;19(4):754-60.

56. Gregoire C, Briquet A, Pirenne C, Lechanteur C, Louis E, Beguin Y. Allogeneic mesenchymal stromal cells for refractory luminal Crohn's disease: a phase I-II study. Dig Liver Dis. 2018;50(11):1251-5.

57. Cassinotti A, Annaloro C, Ardizzone S, Onida F, Della Volpe A, Clerici $M$, et al. Autologous haematopoietic stem cell transplantation without CD34+ cell selection in refractory Crohn's disease. Gut. 2008;57(2):211-7

58. Snowden JA, Ansari A, Sachchithanantham S, Jackson G, Thompson N, Lobo A, et al. Autologous stem cell transplantation in severe treatment-resistant Crohn's disease: long-term follow-up of UK patients treated on compassionate basis. QJM. 2014;107(11):871-7.

59. Ruiz MA, Kaiser RL Jr, de Quadros LG, Piron-Ruiz L, Peña-Arciniegas T, Faria MAG, et al. Low toxicity and favorable clinical and quality of life impact after non-myeloablative autologous hematopoietic stem cell transplant in Crohn's disease. BMC Res Notes. 2017;10(1):495.

60. Oyama Y, Craig RM, Traynor AE, Quigley K, Statkute L, Halverson A, et al. Autologous hematopoietic stem cell transplantation in patients with refractory Crohn's disease. Gastroenterology. 2005;128(3):552-63.

61. Clerici M, Cassinotti A, Onida F, Trabattoni D, Annaloro C, Della Volpe A, et al. Immunomodulatory effects of unselected haematopoietic stem cells autotransplantation in refractory Crohn's disease. Dig Liver Dis. 2011:43(12):946-52.

62. Tomblyn M, Chiller T, Einsele H, Gress R, Sepkowitz K, Storek J, et al. Guidelines for preventing infectious complications among hematopoietic cell transplant recipients: a global perspective. Preface Bone Marrow Transplant. 2009;44(8):453-5.

63. Fukuchi Y, Nakajima H, Sugiyama D, Hirose I, Kitamura T, Tsuji K. Human placenta-derived cells have mesenchymal stem/progenitor cell potential. Stem Cells. 2004;22(5):649-58.

64. Ballester Ferré MP, Boscá-Watts MM, Mínguez Pérez M. Crohn's disease. Med Clin (Barc). 2018;151(1):26-33.

65. Basu S, Liu C, Zhou XK, Nishiguchi R, Ha T, Chen J, et al. GLUT5 is a determinant of dietary fructose-mediated exacerbation of experimental colitis. Am J Physiol Gastrointest Liver Physiol. 2021. https://doi.org/ 10.1152/ajpgi.00059.2021.

66. Gong L, Xiao J, Yi J, Xiao J, Lu F, Liu X. Immunomodulatory effect of serum exosomes from crohn disease on macrophages via let-7b-5p/ TLR4 signaling. Inflamm Bowel Dis. 2021;9:izab32.

67. Liao Y, Xu J, Qin B, Shi J, Qin C, Xie F, et al. Advanced oxidation protein products impair autophagic flux in macrophage by inducing lysosomal dysfunction via activation of PI3K-Akt-mTOR pathway in Crohn's disease. Free Radic Biol Med. 2021;21(172):33-47.

68. Fuss IJ, Heller F, Boirivant M, Leon F, Yoshida M, Fichtner-Feigl S, et al. Nonclassical CD1d-restricted NKT cells that produce IL-13 characterize an atypical Th2 response in ulcerative colitis. J Clin Invest. 2004;113:1490-7.

69. Sartor RB. Microbial influences in inflammatory bowel diseases. Gastroenterology. 2008;134:577-94.

70. Kim SC, Tonkonogy SL, Karrasch T, Jobin C, Sartor RB. Dual-association of gnotobiotic IL-10-/- mice with 2 nonpathogenic commensal bacteria induces aggressive pancolitis. Inflamm Bowel Dis. 2007;13:1457-66.

71. Shale M, Schiering C, Powrie F. CD4+ T-cell subsets in intestinal inflammation. Immunol Rev. 2013;252:164-82.

72. Maul J, Loddenkemper C, Mundt P, Berg E, Giese T, Stallmach A, et al. Peripheral and intestinal regulatory CD4+ CD25(high) T cells in inflammatory bowel disease. Gastroenterology. 2005;128(7):1868-78. 
73. Burt RK, Abinun M, Farge-Bancel D, Fassas A, Hiepe F, Havrdová E, Ikehara S, Loh Y. Risks of immune system treatments. Science. 2010;328(5980):825-6.

74. Heidari N, Abbasi-Kenarsari H, Namaki S, Baghaei K, Zali MR, Ghaffari Khaligh S, et al. Adipose-derived mesenchymal stem cell-secreted exosome alleviates dextran sulfate sodium-induced acute colitis by Treg cell induction and inflammatory cytokine reduction. J Cell Physiol. 2021;236(8):5906-20.

75. An JH, Song WJ, Li Q, Kim SM, Yang Jl, Ryu MO, et al. Prostaglandin E2 secreted from feline adipose tissue-derived mesenchymal stem cells alleviate DSS-induced colitis by increasing regulatory $T$ cells in mice. BMC Vet Res. 2018;14(1):354.

76. Qiu Y, Li MY, Feng T, Feng R, Mao R, Chen BL, et al. Systematic review with meta-analysis: the efficacy and safety of stem cell therapy for Crohn's disease. Stem Cell Res Ther. 2017;8(1):136.

77. Schwartz DA, Loftus EV Jr, Tremaine WJ, Panaccione R, Harmsen WS, Zinsmeister AR, et al. The natural history of fistulizing Crohn's disease in Olmsted County, Minnesota. Gastroenterology. 2002;122(4):875-80.

78. Bislenghi G, Wolthuis A, Van Assche G, Vermeire S, Ferrante M, D'Hoore A. Cx601 (darvadstrocel) for the treatment of perianal fistulizing Crohn's disease. Expert Opin Biol Ther. 2019;19(7):607-16.
79. Panés J, García-Olmo D, Van Assche G, Colombel JF, Reinisch W, Baumgart DC, et al. ADMIRE CD study group collaborators: expanded allogeneic adipose-derived mesenchymal stem cells (Cx601) for complex perianal fistulas in Crohn's disease: a phase 3 randomised, double-blind controlled trial. Lancet. 2016;388(10051):1281-90.

80. Panés J, García-Olmo D, Van Assche G, Colombel JF, Reinisch W, Baumgart DC, et al. ADMIRE CD study group collaborators: long-term efficacy and safety of stem cell therapy (Cx601) for complex perianal fistulas in patients with Crohn's disease. Gastroenterology. 2018;154(5):1334-1342.e4.

81. de la Portilla F, Alba F, García-Olmo D, Herrerías JM, González FX, Galindo A. Expanded allogeneic adipose-derived stem cells (eASCs) for the treatment of complex perianal fistula in Crohn's disease: results from a multicenter phase I/Ila clinical trial. Int J Colorectal Dis. 2013;28(3):313-23.

\section{Publisher's Note}

Springer Nature remains neutral with regard to jurisdictional claims in published maps and institutional affiliations.
Ready to submit your research? Choose BMC and benefit from:

- fast, convenient online submission

- thorough peer review by experienced researchers in your field

- rapid publication on acceptance

- support for research data, including large and complex data types

- gold Open Access which fosters wider collaboration and increased citations

- maximum visibility for your research: over $100 \mathrm{M}$ website views per year

At BMC, research is always in progress.

Learn more biomedcentral.com/submissions 